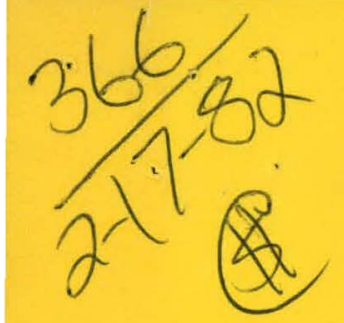

\title{
MLM-280MASTER
}

\section{A Tested Method to Minimize Plutonium Assay Discrepancies Between Laboratories}

Raymond J. Seiler, Ronald L. Goss, W. William Rodenburg, and Donald R. Rogers

January 29, 1982

\section{DO NNOT MICROFILM COVER}

\section{MOUND FACILITY}

Miamisburg, Ohio 45342

operated by

Monsanto

MONSANTO RESEARCH CORPORATION

a subsidiary of Monsanto Company

for the

U. S. DEPARTMENT OF ENERGY

Eontract.Nn. TE-ALD4-76-LPOODS3 


\section{DISCLAIMER}

This report was prepared as an account of work sponsored by an agency of the United States Government. Neither the United States Government nor any agency Thereof, nor any of their employees, makes any warranty, express or implied, or assumes any legal liability or responsibility for the accuracy, completeness, or usefulness of any information, apparatus, product, or process disclosed, or represents that its use would not infringe privately owned rights. Reference herein to any specific commercial product, process, or service by trade name, trademark, manufacturer, or otherwise does not necessarily constitute or imply its endorsement, recommendation, or favoring by the United States Government or any agency thereof. The views and opinions of authors expressed herein do not necessarily state or reflect those of the United States Government or any agency thereof. 


\section{DISCLAIMER}

Portions of this document may be illegible in electronic image products. Images are produced from the best available original document. 


\section{DO INOT MICROFILM COVER}

\section{NOTICE}

This report was prepared as an account of work sponsored by an agency of the United States Government. Neither the United States nor any agency thereof, nor any of their employees, makes any warranty, expressed or implied, or assumes any legal liability or responsibility for any third party's use or the results of such use of any information, apparatus, product or process disclosed in this report, or represents that its use by such third party would not infringe privately owned rights.

Printed in the United States of America Available from

National Technical Information Service U. S. Department of Commerce 5285 Port Royal Road Springfield, VA 22161

NTIS price codes

Printed copy: 1(1)?

Microfiche copy: A01 


\section{A Tested Method to Minimize Plutonium Assay Discrepancies Between Laboratories}

Raymond J. Seiler, Ronald L. Goss, W. William Rodenburg, and Donald R. Rogers.

Issued: January 29, 1982

\section{MOUND FACILITY}

Miamisburg, Onio 45342

operated by

MONSANTO RESEARCH CORPORATION

a subsidiary of Monsanto Company

for the

\section{U. S. DEPARTMENT OF ENERGY}

Contract No. DE-ACO4-76-DPODO53 


\section{Contents}

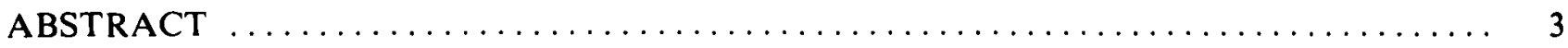

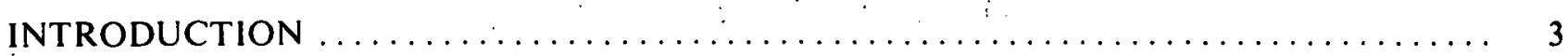

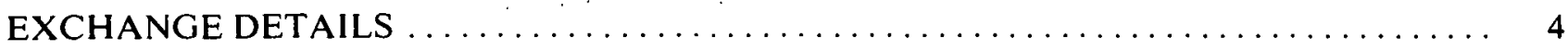

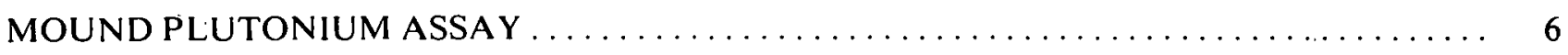

NBL PLUTONIUM ASSAY $\ldots \ldots \ldots \ldots \ldots \ldots \ldots \ldots \ldots \ldots \ldots \ldots \ldots \ldots \ldots \ldots \ldots$

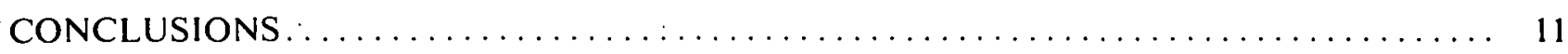

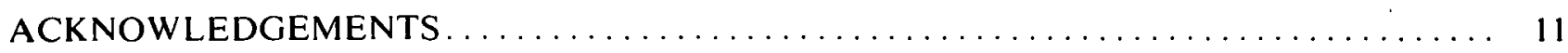

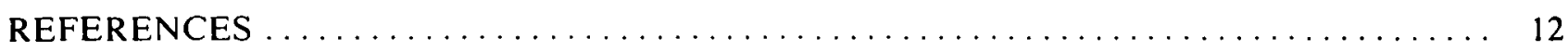

APPENDIX: Decay Corrected Data $\ldots \ldots \ldots \ldots \ldots \ldots \ldots \ldots \ldots \ldots \ldots \ldots \ldots \ldots \ldots$

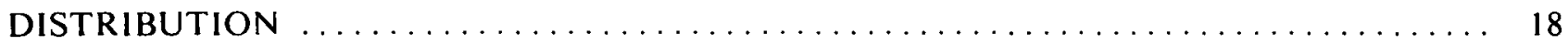




\section{Abstract}

Plutonium assay differences are frequently observed between laboratories exchanging plutonium dioxide powders. These differences are commonly the result of chemical changes and/or nonhomogeneities in sampled materials. The irregularities are often caused by moisture absorption during sampling, packaging, shipment, and storage of the materials. $A$ method is proposed which eliminates the effects of chemical change in samples, particularly moisture absorption, and minimizes sampling error. A nondestructive thermal watts/gram test on every preweighed sample and total dissolution of these samples for chemical assay are the primary features which make this method effective. Because this method minimizes the error related to exchange material, it is possible to design an interlaboratory exchange program which demonstrates the assay capabilities of the participants. Exchange parlicipants can be confident that the samples they receive are representative of the source material within narrow limits of error.

In an experiment performed to demonstrate the effectiveness of this method, three $\mathrm{PuO}_{2}$ batches of varying isotopic composition were synthesized at Mound to be used in the exchange tests. Powder sample aliquots from each batch were weighed directly into their vials under controlled atmospheric conditions. Calorimetric heat measurements were made on each vial to test homogeneity and verify sample weight. Six vials of each batch were chemically assayed at Mound and six at NBL (New Brunswick Laboratory). Both laboratories chose controlled-potential coulometry as the chemical assay technique because of its demonstrated precision and accuracy. Total dissolution of preweighed exchange samples eliminated the need for laborious and usually futile heating to return the material to its original condition. The mean chemical assay values obtained by Mound and NBL agree to within $0.01 \%$ for each of the compositions tested. Testing of both chemical assay and calorimetric data revealed no sampling error throughout the experiment.

\section{Introduction}

The reasons for plutonium assay discrepancies involving the exchange of $\mathrm{PuO}_{2}$ powders for laboratory evaluation programs are of ten moisture absorption and/or chemical nonhomogeneity. When moisture absorption occurs during packaging, shipment, or storage of the sample or the bulk material, the sample is no longer representative of the bulk material. Sampling and subsampling errors caused by nonhomogeneities in plutonium concentration are frequently the result of water uptake, which is seldom uniform. Once water is absorbed, samples of most $\mathrm{PuO}_{2}$ batches cannot be returned to their original plutonium concentration by heating at any temperature. Moisture absorption causes assay values of laboratory evaluation samples to differ substantially from those analyzed to set the reference value. Frequently, the same phenomenon is responsible for errors in chemical assay between shipper and receiver laboratories. At the same time, it is possible that neither laboratory has analyzed a sample that is representative of the bulk shipment.

A method was developed to test for, and minimize, plutonium assay sampling error before the exchange of $\mathrm{PuO}_{2}$ samples. This method was successfully demonstrated by an exchange of samples from three batches of reactor grade plutonium dioxide powder between Mound and NBL. To minimize sampling error, each batch was mechanically mixed in an inert atmosphere. To eliminate the effects of chemical change, specifically sorbed water samples for 
this exchange were weighed into tared glass vials and sealed before removal from the inert boxline. Once the sample is weighed, chemical changes in the powder cannot affect the total plutonium content of the vial. Each sample vial was made up so that the thermal output would be approximately $10 \mathrm{~mW}$. The weight of the samples ranged from 1.2 to $4.0 \mathrm{~g}$ depending on the isotopic composition. Each vial was tested calorimetrically for chemical nonhomogeneity and weight verification. No sample-to-sample nonhomogeneity could be detected in any of the three batches by testing the thermal watts/gram calorimetry data. Six sample vials of each composition were chemically assayed at Mound and six, at NBL.

Dissolution of the entire content of each vial prevented the possibility of subsampling error. Quantitative transfer of the powder from the vials was quick and simple. After the samples were poured in, both the vials and their Teflon gaskets were placed in the dissolution vessels. The mean chemical assay values obtained by Mound and NBL agree to within $0.01 \%$ for each of the three batches tested. The relative standard deviation was low $(<0.07 \%)$ inall cases. The following sections provide details of: a) isotopic batch make-up, (b) sample preparation, c) nonhomogeneity and sampling error tests, and d) chemical assay procedures and results.

\section{Exchange details}

Three batches of $\mathrm{PuO}_{2}$, having different isotopic compositions, were prepared to simulate the abundance of low, medium, and high burn-up commercial ' reactor fuel: "Plutonium chemical assay measurements were performed by analytical personnel at Mound and NBL. The overall experimental flow chart including material preparation steps for each batch is shown in Figure 1.

\section{Preparation of isotopic blend batches}

Calculated quantities of plutonium nitrate solutions of known concentration and isotopic composition were combined to yield a solution of desired isotopic composition. The resulting isotopic composition was checked using mass spectrometry and alpha counting before further processing. The isotopic compositions of these batches are listed in Table 1.
Table 1 - ISOTOPIC COMPOSITION OF $\mathrm{PuO}_{2}$ BATCHES

\begin{tabular}{|c|c|c|c|}
\hline : & & wt $\%$ & \\
\hline Isotope & Batch 1 & Batch 2 & Batch 3 \\
\hline $\mathrm{Pu}-238$ & 0.06 & 0.25 & 1.1 \\
\hline $\mathrm{Pu}-239$ & 86.6 . & 73.2 & 70.3 \\
\hline $\mathrm{Pu}-240$ & 11.7 & 22.6 & $24: 1$ \\
\hline $\mathrm{Pu}-241$ & 1.5 & 3.0 & 3.2 \\
\hline $\mathrm{Pu}-242$ & 0.2 & 1.0 & $1: 2$ \\
\hline Am-241 & 0.01 & 0.06 & 0.02 \\
\hline $\begin{array}{c}\text { Thermal Power } \\
\text { (mW/g Pu) }\end{array}$ & 2.88 & 4.66 & 9.70 \\
\hline
\end{tabular}

Sub-batches of solution containing 20-30 g of plutonium nitrate were converted to plutonium dioxide by precipitating tbe plutonium as oxalate and igniting it at $800^{\circ} \mathrm{C}$ for 2 .hr. Four or five of these sub-batches were combined and mixed. in an inert atmosphere for $2 \mathrm{hr}$, with a twin-shell blender. Analytical samples were taken after blending to check isotopic composition and impurity levels.

\section{Preparation of exchange samples}

The paper gaskets from the Bakelite caps of 1-dram. glass vials were replaced with Teflon gaskets. Next the caps, gaskets, and vials were cleaned and carefully dried in a vacuum oven. At least 14 samples were divided from each batch of $\mathrm{PuO}_{2}$ using a cone-and-quartering method (ASTM E300-30.5.1), in an inert atmosphere boxline. The powder aliquots were weighed directly into the tared glass vials on a Mettler $\mathrm{H}-18$ balance. The samples were made up to have a thermal output of approximately 10 $\mathrm{mW}$ each. The approximate sample weights were $4.0,2.5$ and $1.25 \mathrm{~g}$ for Batches 1,2 , and 3, respectively. The vials were then capped and taped for Batches 2 and 3. Two samples from Batch 1 delivered to NBL were compromised when their caps loosened during shipment: Taping the caps for the next two shipments prevented any further problems: 


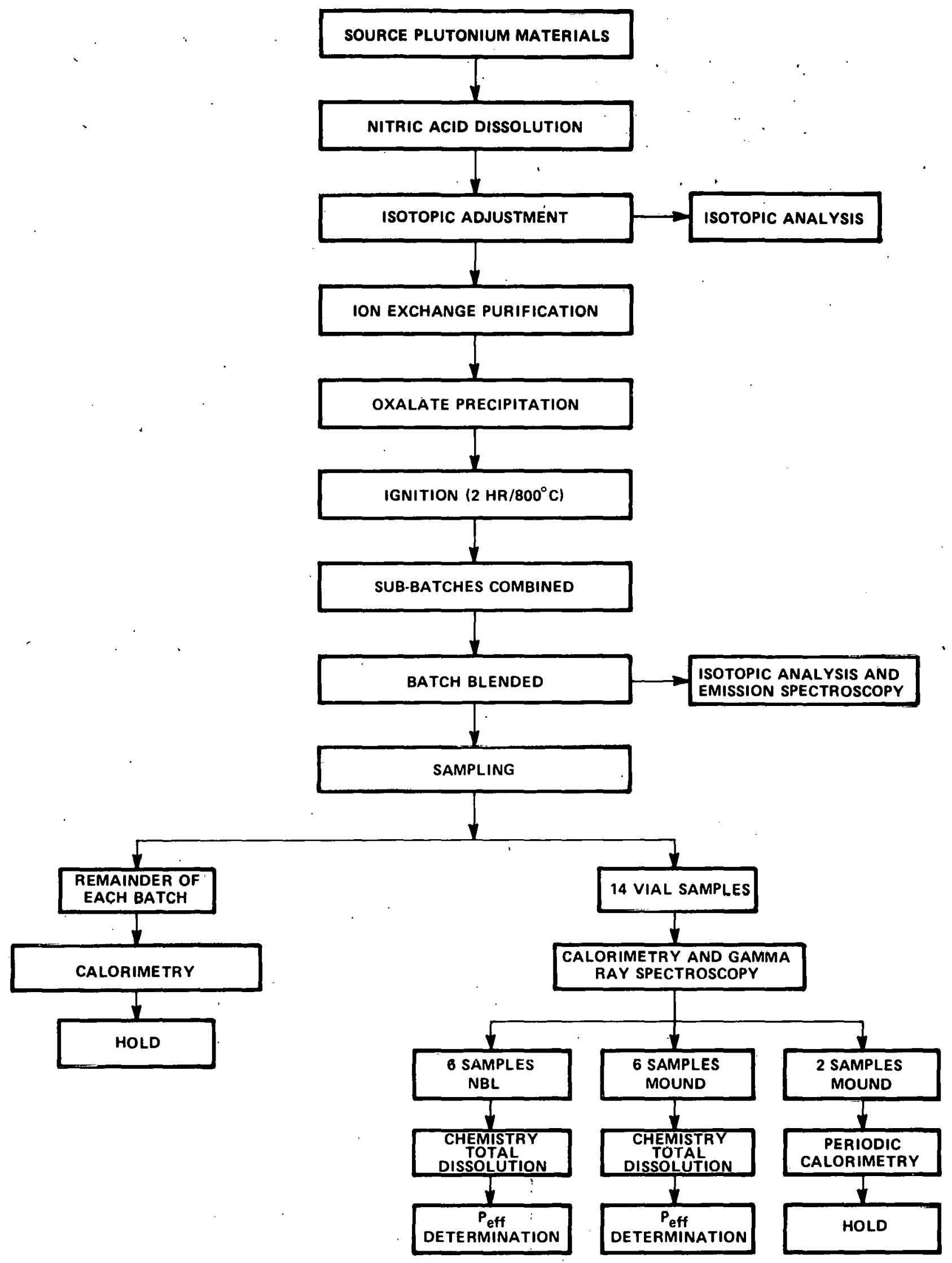

FIGURE 1 - Individual batch preparation and sampling at Mound. 


\section{Calorimetric watts/gram test}

After the exchange sample vials of each batch were withdrawn from the boxline, the thermal output of each sample was measured. The rela-, tive standard deviation (RSD), of the thermal measurements was estimated to be $0.03 \%$ based on eight measurements of Mound heat standards over a 6-mo period. The relative standard deviation of the weight measurements was estimated to be $0.009 \%$. The watts/gram $(\mathrm{W} / \mathrm{M})$ values from each batch of samples were compiled and tested for homogeneity and sample weighing error. The following model was used:

$$
\begin{aligned}
\mathrm{S}^{2}{ }_{W / M}= & (\mathrm{W} / \mathrm{M})^{2}\left(\frac{\mathrm{S}_{W}}{\mathrm{~W}}\right)^{2}+(\mathrm{W} / \mathrm{M})^{2}\left(\frac{\mathrm{S}_{M}}{\mathrm{M}}\right) \\
& +\mathrm{S}_{\text {samp }}^{2}+\mathrm{S}^{2}{ }_{I}
\end{aligned}
$$

where:

$$
\begin{aligned}
& \mathrm{S}^{2}{ }_{w / M}=\text { the } \text { variance in the watts/gram } \\
& \text { determination of the samples. } \\
& (\mathrm{W} / \mathrm{M})^{2}\left(\frac{\mathrm{S}_{\mathrm{W}}}{\mathrm{W}}\right)^{2}=\text { the variance due to the } \\
& (\mathrm{W} / \mathrm{M})^{2}\left(\frac{\mathrm{S}_{M}}{\mathrm{M}}\right)^{2}=\text { the variance due to the mea- } \\
& \mathrm{S}_{\text {samp }}^{2} \quad=\text { the variance potentially due to }
\end{aligned}
$$

An F-ratio was used to test for the significance of the variance due to sampling or interferences to the power measurement; $\mathrm{S}_{\text {samp }}^{2}$ and $\mathrm{S}^{2}$, respectively:

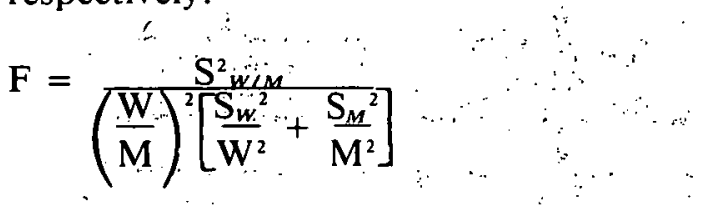

The results of the three tests for sample homogeneity are summarized in Table 2.
The computed $F$ ratios are well below the critical value, $F_{0.95}$. Therefore, the data support the hypothèsis thät there are no significant sampling errors" The "data obtained from the thermal power measurements of individual samples are compiled in Tables 1, 2, and 3 of the Appendix.

\section{Mound plutonium assay Dissolution}

The contents of the analytical sample vials were emptied into a $200-\mathrm{ml}$ Teflon dissolution vessel (Figure 2): Next,the, glass vial and the Teflon gasket from the cap were also placed in this vessel. After the addition of $80 \mathrm{ml}$ of $16 \mathrm{M}$ $\mathrm{HNO}_{3}-0.1 \mathrm{M}$ HF solution, the vessels were placed in an oven controlled at a temperature of $105^{\circ} \mathrm{C}$ overnight (approximately $18 \mathrm{hr}$ ). The solution was then transferred to a tared 4-ounce polyethylene bottle with dilute nitric acid.

\section{Sample preparation and titration}

From the 4-ounce polyethylene bottle, two weigheed aliquots' were taken for coulometry; aliquots were also taken for spectrophotometric iron determination, impurity analysis, and isotopic analysis. The flow of chemical samples within the Mound analysis scheme is shown in Figure 3. After dilution of the coulometry aliquots, three subaliquots (each containing about $8 \mathrm{mg}$ of plutonium) were weighed into glass titration cells. These subaliquots were fumed to dryness twice with $\mathrm{H}_{2} \mathrm{SO}_{4}$ and titrated according to a Mound standard analytical procedure [1]. This controlled potential coulometric procedure was adapted from one described by Rodden [2]. The procedure is performed in a medium of 0.5 M $\mathrm{H}_{2} \mathrm{SO}_{4}$ with a platinum..working electrode made from 45 mesh gauze. Along with each day's samples, at least five aliquots of a. standard solution made from NBS 949e plutonium metal were titrated to calibrate the coulometry system. Both samples and standards were corrected fór atomic mass, plutonium decay, and iron concentration. The three titration values were averaged to yield one value for each solution aliquot taken. The plutonium assay results derived from the titration of these solution aliquots are listed in full in Tables 4,5 , and 6 of the Appendix. 


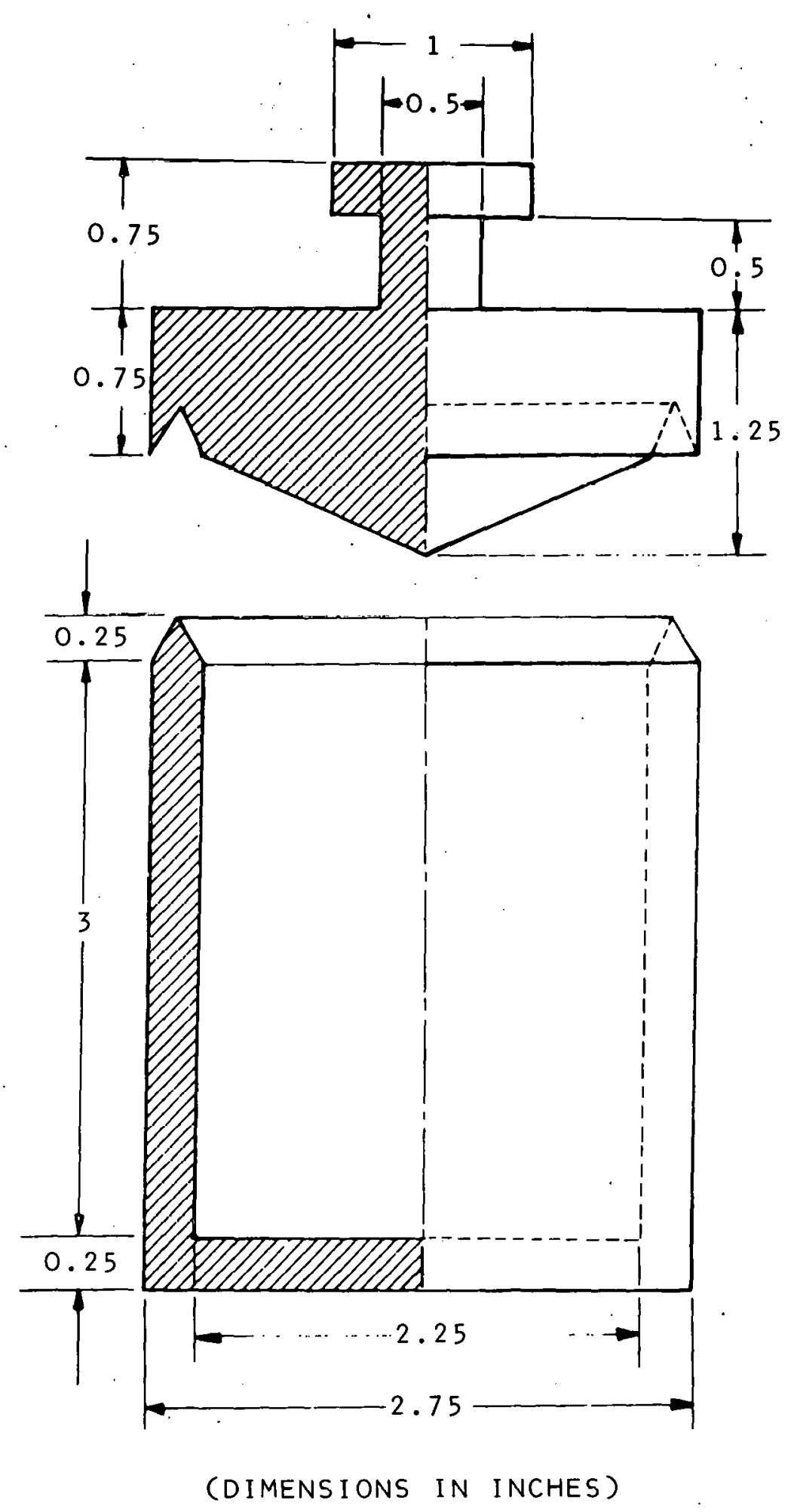

FIGURE 2 - Solid teflon dissolution vessel, suitable for the dissolution of up to $8 \mathrm{~g}$ of $\mathrm{PuO}_{2}$ or $(\mathrm{Pu}, \mathrm{U}) \mathrm{O}_{2}$. The maximum recommended solution volume is $100 \mathrm{ml}$ : 
Table 2 - SAMPLE HOMOGENEITY

$\begin{array}{ccccccccc}\text { Batch } & \frac{\mathrm{S}_{W}^{2}}{\mathrm{M}} & \frac{\left(\frac{\mathrm{W}}{\mathrm{M}}\right)^{2}}{\left(\frac{\mathrm{S}_{W}}{\mathrm{~W}}\right)^{2}} & \frac{\left(\frac{\mathrm{S}_{M}}{\mathrm{M}}\right)^{2}}{\mathrm{~F}} & \frac{\nu_{1}, \nu_{2}}{\mathrm{~F}_{0.95}} & & & & \\ 1 & 1.00 \times 10^{-12} & 6.42 \times 10^{-6} & 9.0 \times 10^{-8} & 0.8 \times 10^{-8} & 1.58 & 9,7 & 3.68 \\ 2 & 4.41 \times 10^{-12} & 1.68 \times 10^{-5} & 9.0 \times 10^{-8} & 0.8 \times 10^{-8} & 2.68 & 10,7 & 3.64 \\ 3 & 5.29 \times 10^{-12} & 7.28 \times 10^{-5} & 9.0 \times 10^{-8} & 0.8 \times 10^{-8} & 0.74 & 11,7 & 3.61\end{array}$

\section{NBL plutonium assay Dissolution and titration}

The contents of each sample vial were emptied into a 250-ml Teflon beaker. The vial was then rinsed with $8 \underline{\mathrm{M}} \mathrm{HNO}_{3}$ and placed with the gasket in another 250-ml Teflon beaker with $8 \underline{\mathrm{M}}$ $\mathrm{HNO}_{3}$. Dissolution of the powder portion was accomplished by adding approximately $100 \mathrm{ml}$ of $8 \mathrm{M} \mathrm{HNO}$ - $\mathrm{HF}$ solution and heating below the boiling point. After the sample was completely dissolved, the two solutions were combined, taken to low volume, and transferred into a 500-ml tared bottle. Two solution aliquots were then weighed from a polyethylene squeeze bottle and fumed twice to dryness with $\mathrm{H}_{2} \mathrm{SO}_{4}$. Each aliquot was then purified using an anionexchange separation procedure [3]. The eluate was collected and fumed twice to dryness with $\mathrm{H}_{2} \mathrm{SO}_{4}$ in the glass titration cell. The aliquots were then titrated by the controlled-potential coulometric method developed at NBL $[4,5]$. This titration is performed at the surface of a gold electrode in $0.9 \mathrm{M} \mathrm{HNO}_{3}$ acid medium. Plutonium assay values are based upon electrical calibration of the M-T Model 3 coulometric system [6]. Chemical standards made from NBS-944 plutonium sulfate tetrahydrate were analyzed to monitor instrument performance. Figure 4 outlines the flow of samples at NBL. The plutonium assay results derived from the titration of these aliquots are compiled in Tables 4,5 , and 6 of the Appendix. The comparison of Mound vs. NBL chemical assay results is shown in Table 3.

\section{Chemical data test}

An $F$ ratio was also used to test the chemical assay data for the significant sampling, transfer, and dissolution error. The following model was used:

$$
\mathrm{S}_{B}^{2}=\mathrm{S}^{2}{ }_{W S}+\mathrm{S}^{2}{ }_{s u m p}+\mathrm{S}^{2}{ }_{D}+\mathrm{S}^{2}{ }_{T}
$$

where: $\mathrm{S}^{2} \quad=$ variance of plutonium values between samples assayed.

$\mathrm{S}^{2} w s=$ variance of plutonium values within samples assayed.

$\mathrm{S}_{\text {samp }}^{2}=$ variance potentially due to sampling which could be the result of chemical or isotopic nonhomogeneity within the blend batch.

$\mathrm{S}^{2}{ }_{D} \quad=$ variance potentially due to incomplete dissolution or loss of sample material during dissolution.

$\mathrm{S}^{2}{ }_{T} \quad=$ variance potentially due to 'loss of sample material during transfer in any chemical assay step. 


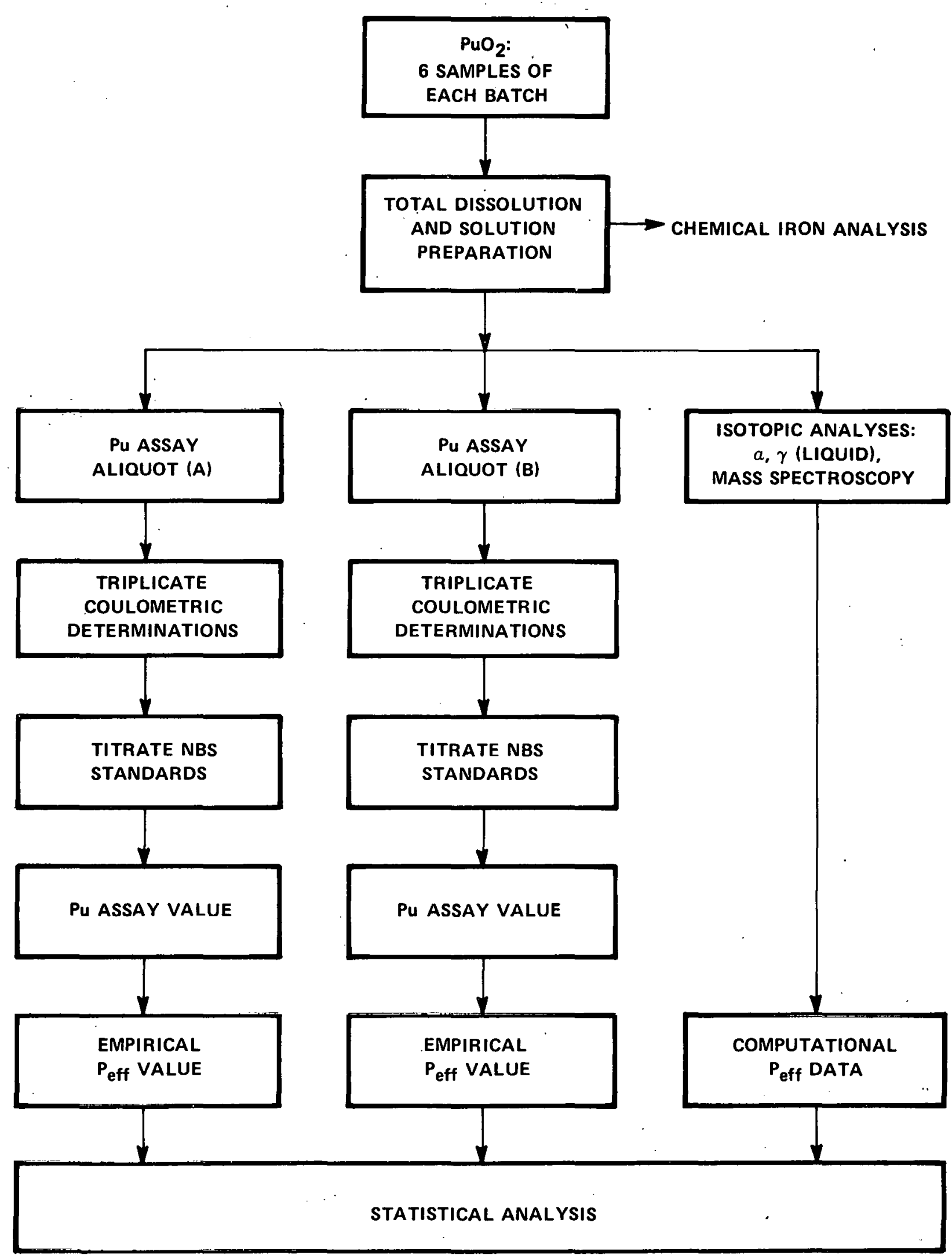

FIGURE 3 - Flow of individual samples at Mound. 


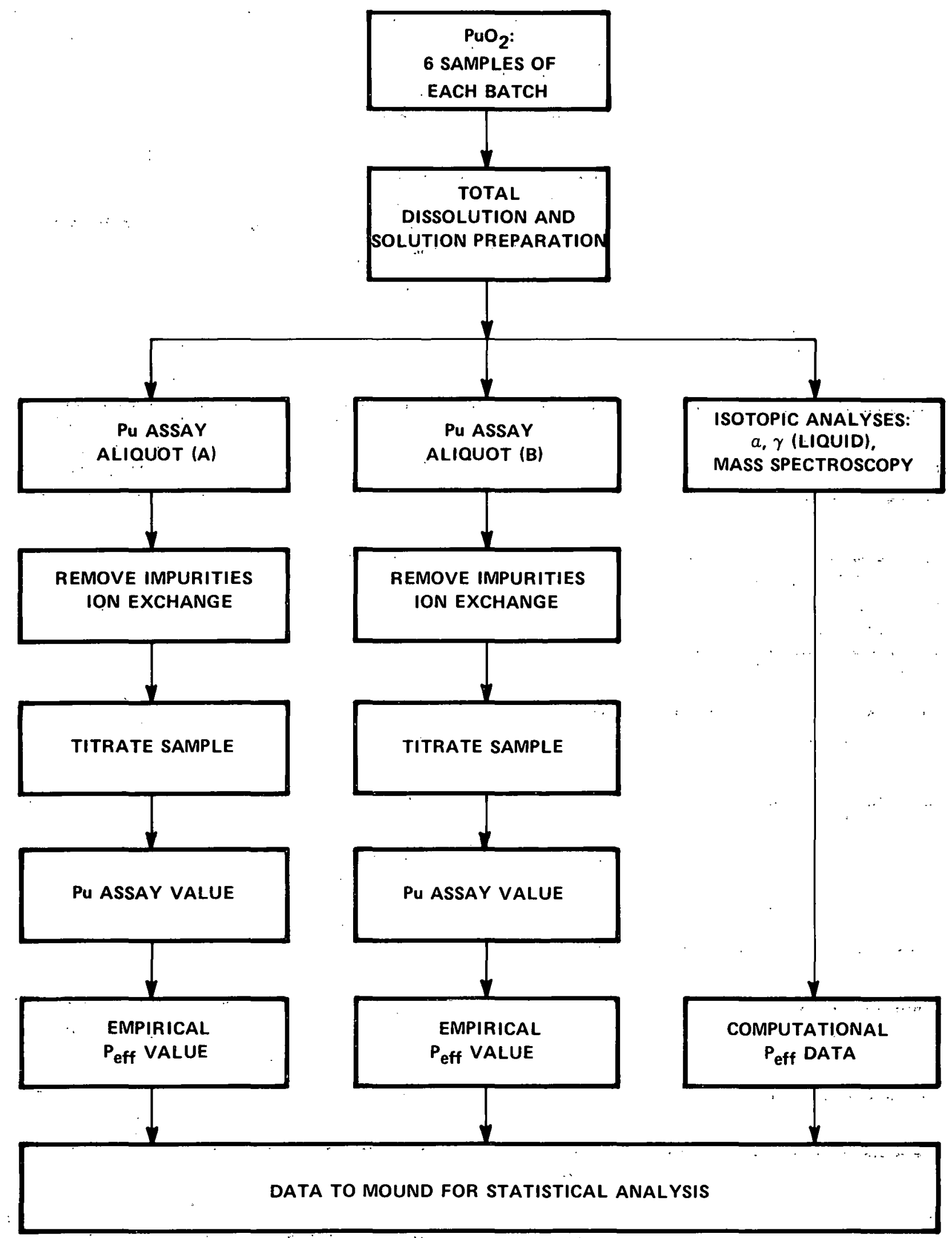

FIGURE 4 - Flow of individual samples at NBL. 
Table 3 - COMPARISON OF Pu CHEMICAL ASSAY VALUES FROM MOUND AND NBL

\begin{tabular}{|c|c|c|c|c|c|}
\hline Batch & Site & $\begin{array}{c}\begin{array}{c}\text { Mean } \\
(\text { wt } \%)^{a} \\
\end{array} \\
\end{array}$ & $\begin{array}{l}\text { RSD } \\
(\%)\end{array}$ & $\begin{array}{c}\text { SD of Mean } \\
(\%) \\
\end{array}$ & $N(R)^{b}$ \\
\hline 1 & Mound & 88.056 & \pm 0.058 & \pm 0.015 & $6(2)$ \\
\hline 1 & $\begin{array}{l}\text { NBL } \\
\text { Difference (wt } \% \text { ) }\end{array}$ & $\begin{array}{l}88.060 \\
+0.004\end{array}$ & \pm 0.030 & \pm 0.009 & $4(2)$ \\
\hline 2 & Mound & 87.965 & \pm 0.049 & \pm 0.012 & $6(2)$ \\
\hline 2 & $\begin{array}{l}\text { NBL } \\
\quad \text { Difference (wt \%) }\end{array}$ & $\begin{array}{l}87.960 \\
-0.005\end{array}$ & \pm 0.058 & \pm 0.015 & $6(2)$ \\
\hline 3 & Mound & 87.976 & \pm 0.069 & \pm 0.018 & $6(2)$ \\
\hline 3 & $\begin{array}{l}\text { NBL } \\
\quad \text { Difference (wt } \%)\end{array}$ & $\begin{array}{l}87.978 \\
+0.002\end{array}$ & \pm 0.069 & \pm 0.018 & $6(2)$ \\
\hline
\end{tabular}

aWithin batch $\mathrm{Pu}$ assay values, decay corrected to a common date.

$b_{N}(R)$ represents (the number of sample vials analyzed) $x$ (the number of replicates per vial).

An $\mathrm{F}$ ratio was used to test for significance of the variance due to sampling, dissolution, and transfer, $\mathrm{S}_{\text {samp }}^{2}, \mathrm{~S}^{2}{ }_{D}$, and $\mathrm{S}_{T}^{2}$, respectively:

$$
\mathrm{F}=\frac{\mathrm{S}^{2}{ }_{B}}{\mathrm{~S}^{2}{ }_{w s}}
$$

The $\mathrm{F}$ ratios calculated from both Mound and NBL data for all three batches are shown in Table 4.

The computed $\mathrm{F}$ ratios are well below the critical value, $F_{0.95}$. Therefore, the chemical assay data support the hypothesis that there is no significant amount of matcrial lost in the dissolution and transfer steps of the assay procedure and that the samples arc homogencous with respect to plutonium content.

\section{Conclusions}

The calorimetric and chemical assay data reported for the three batches of $\mathrm{PuO}_{2}$ exchanged demonstrate a method that would eliminate interlaboratory exchange assay discrepancies caused by the reactive nature of this material. Several design elements contributed to the success of this exchange. First, preweighed samples avoid the effects of chemical change and permit the exchange of blind samples. Second, total dissolution avoids subsampling errors without laborious calcining, heating or mathematical calculations. Third, a nondestructive watts/gram test on every sample validates sample weight measurements and tests for sample-to-sample chemical and isotopic variability.

The interlaboratory chemical assay of all three batches agrees within $0.01 \%$ relative. Statistical testing of both calorimetric and chemical data revealed no sampling error throughout the exchange.

\section{Acknowledgements}

Major efforts for chemical analyses of these materials were provided by: B. P. Freeman, M. K. Holland, S. A. Malone, C. E. Pietri and J. R. Weiss of New Brunswick Laboratory and V. L. George, J. R. Tackett, K. M. Muldoon and W. E. Sheehan of Mound Facility. 
Table 4 - CHEMICAL ASSAY TEST FOR SAMPLE HOMOGENEITY PLUS TRANSFER AND DISSOLUTION ERROR

\begin{tabular}{|c|c|c|c|c|c|c|}
\hline Batch & Site & $\mathrm{S}_{B}^{2}$ & $\mathrm{~S}_{w S}$ & $\mathrm{~F}$ & $v_{1}, v_{2}$ & $F_{0.95}$ \\
\hline 1 & Mound & 0.00230 & 0.00096 & 2.40 & 5,6 & 4.39 \\
\hline 1 & NBL & 0.00044 & 0.00053 & 0.83 & 3,4 & 6.59 \\
\hline 2 & Mound & 0.00168 & 0.00068 & 2.47 & 5,6 & 4.39 \\
\hline 2 & NBL & 0.00160 & 0.00221 & 0.72 & 5,6 & 4.39 \\
\hline 3 & Mound & 0.00314 & 0.00152 & 2.07 & 5,6 & 4.39 \\
\hline 3 & NBL & 0.00292 & 0.00185 & 1.58 & 5,6 & 4.39 \\
\hline
\end{tabular}

\section{References}

1. PD-80026, Mound Facility Standard Analytical Procedures, Operation 102, "Plutonium Assay by Controlled Potential Coulometry," Mound Facility, Miamisburg, Ohio, 36 pp.

2. C. J. Rodden (ed.), Selected Measurement Methods for Plutonium and Uranium in the Nuclear Fuel Cycle, U. S. Atomic Energy Commission Report TID-7029 (2nd ed.), pp. 314-326 (1972).
3. Separation of Plutonium by Mini AnionExchange, NBL-PC-IE-2.

4. M. K. Holland, J. R. Weiss and C. E. Pietri, Anal. Chem., 50, 239 (1978).

5. Controlled-Potential Coulometric (CPC) Determination of Plutonium with ControlledPotential Adjustment Technique, NBL-PCPA-6.

6. M-T Model 3 Instrument Calibration Procedure, NBL-PC-CP-1. 


\section{APPENDIX: Decay corrected data}

\begin{tabular}{|c|c|c|}
\hline \multirow[b]{2}{*}{ Sample* ID } & \multicolumn{2}{|c|}{ Thermal Power $(\mathrm{W} / \mathrm{g})$} \\
\hline & $\begin{array}{l}\text { Sample } \\
\text { Reading } \\
\end{array}$ & Vial Av \\
\hline 1002 & $\begin{array}{l}0.0025348 \\
0.0025347\end{array}$ & 0.0025348 \\
\hline 1006 & $\begin{array}{l}0.0025345 \\
0.0025352\end{array}$ & 0.0025348 \\
\hline 1010 & $\begin{array}{l}0.0025348 \\
0.0025348\end{array}$ & 0.0025348 \\
\hline 1014 & $\begin{array}{l}0.0025356 \\
0.0025358\end{array}$ & 0.0025357 \\
\hline 1016 & $\begin{array}{l}0.0025354 \\
0.0025349\end{array}$ & 0.0025352 \\
\hline 1017 & $\begin{array}{l}0.0025344 \\
0.0025347\end{array}$ & 0.0025346 \\
\hline 1004 & $\begin{array}{l}0.0025358 \\
0.0025350\end{array}$ & 0.0025354 \\
\hline 1007 & $\begin{array}{l}0.0025342 \\
0.0025337\end{array}$ & 0.0025340 \\
\hline 1008 & $\begin{array}{l}0.0025346 \\
0.0025346\end{array}$ & 0.0025346 \\
\hline 1011 & $\begin{array}{l}0.0025326 \\
0.0025319\end{array}$ & 0.0025322 \\
\hline
\end{tabular}

Mean

0.0025346

Standard Deviation

$\begin{array}{llc}\text { Between Vials } \quad \pm 0.0000010 & \begin{array}{c}0.038 \%, \\ \text { relative }\end{array} \\ \text { Within Vial } & \pm 0.0000003 & \begin{array}{c}0.012 \% \\ \text { relative }\end{array}\end{array}$

*Only samples which were assayed chemically are included in these data. 
Table 2 - MOUND CALORIMETRY DATA FOR PLUTONIUM BATCH 2 (Common Decay Date 6/01/77)

Thermal Power $(\mathrm{W} / \mathrm{g})$

\begin{tabular}{|c|c|c|}
\hline Sample* ID & $\begin{array}{l}\text { Sample } \\
\text { Reading } \\
\end{array}$ & Vial Av \\
\hline 2015 & $\begin{array}{l}0.0040962 \\
0.0040969\end{array}$ & 0.0040966 \\
\hline 2020 & $\begin{array}{l}0.0000000 \\
0.0000000\end{array}$ & \\
\hline 2017 & $\begin{array}{l}0.0041022 \\
0.0041026\end{array}$ & 0.0041024 \\
\hline 2010 & $\begin{array}{l}0.0040969 \\
0.0040969\end{array}$ & 0.0040969 \\
\hline 2019 & $\begin{array}{l}0.0040967 \\
0: 0040981\end{array}$ & 0.0040974 \\
\hline 2007 & $\begin{array}{l}0.0040960 \\
0.0040984\end{array}$ & 0.0040972 \\
\hline 2009 & $\begin{array}{l}0.0041004 \\
0.0040988\end{array}$ & 0.0040996 \\
\hline 2001 & $\begin{array}{l}0.0040972 \\
0.0040960\end{array}$ & 0.0040966 \\
\hline 2013 & $\begin{array}{l}0.0040955 \\
0.0040947\end{array}$ & 0.0040951 \\
\hline 2005 & $\begin{array}{l}0.0040980 \\
0.0040971\end{array}$ & 0.0040976 \\
\hline 2018 & $\begin{array}{l}0.0040982 \\
0.0040966\end{array}$ & 0.0040974 \\
\hline 2012 & $\begin{array}{l}0.0040959 \\
0.0040935\end{array}$ & 0.0040947 \\
\hline
\end{tabular}

Mean

0.0040974

Standard Deviation

Between Vials

0.0000021

$0.051 \%$, relative

Within Vial
$0.0000010 \therefore 0.025 \%$, relative
Table 3 MOUND CALORIMETRY DATA FOR PLUTONIUM BATCH 3 (Common Decay Date 9/01/77)

\begin{tabular}{|c|c|c|}
\hline \multirow{2}{*}{ Sample* ID } & \multicolumn{2}{|c|}{ Thermal Power $(\mathrm{W} / \mathrm{g})$} \\
\hline & $\begin{array}{l}\text { Sample } \\
\text { Reading }\end{array}$ & Vial Av \\
\hline 3109 & $\begin{array}{l}0.0085314 \\
0.0085314\end{array}$ & 0.0085314 \\
\hline 3105 & $\begin{array}{l}0.0085339 \\
0.0085339\end{array}$ & 0.0085339 \\
\hline 3108 & $\begin{array}{l}0.0085297 \\
0.0085300\end{array}$ & 0.0085298 \\
\hline 3.106 & $\begin{array}{l}0.0085261 \\
0.0085261\end{array}$ & 0.0085261 \\
\hline 3103 & $\begin{array}{l}0.0085286 \\
0.0085286\end{array}$ & 0.0085286 \\
\hline 3117. & $\begin{array}{l}0.0085299 \\
0.0085299\end{array}$ & 0.0085299 \\
\hline 3101 & $\begin{array}{l}0.0085327 \\
0.0085327\end{array}$ & 0.0085327 \\
\hline 3111 & $\begin{array}{l}0.0085295 \\
0.0085295\end{array}$ & 0.0085295 \\
\hline 3102 & $\begin{array}{l}0.0085314 \\
0.0085314\end{array}$ & 0.0085314 \\
\hline 3115 & $\begin{array}{l}0.0085274 \\
0.0085274\end{array}$ & 0.0085274 \\
\hline 3113 & $\begin{array}{l}0.0085276 \\
0.0085276\end{array}$ & 0.0085276 \\
\hline 3107 & $\begin{array}{r}0.0085303 \\
0.0085303\end{array}$ & 0.0085303 \\
\hline
\end{tabular}

Mean.

0.0085299

Standard Deviation.

Between Vials

0.0000023

$0.027 \%$, relative

Within Vial

0.0000000

$0.00 \%$, relative
*Only samples which were assayed chemically are included in these data.
* Only samples which were assayed chemically are included in these data. 
Table 4 - CHEMICAL ASSAY DATA FOR PLUTONIUM BATCH 1 (Common Decay Date 9/01/76)

Mound

\begin{tabular}{|c|c|c|c|}
\hline \multirow[b]{2}{*}{ Sample ID } & \multirow[b]{2}{*}{ Aliquot ID } & \multicolumn{2}{|c|}{ wt $\% \mathrm{Pu}$} \\
\hline & & $\begin{array}{c}\text { Aliquot } \\
\text { Value }\end{array}$ & Vial A \\
\hline 1002 & $\begin{array}{l}X 0 \\
X 1\end{array}$ & $\begin{array}{l}88.100 \\
88.102\end{array}$ & 88.101 \\
\hline 1006 & $\begin{array}{l}X 0 \\
\times 1\end{array}$ & $\begin{array}{l}88.128 \\
88.096\end{array}$ & 88.112 \\
\hline 1010 & $\begin{array}{l}X 0 \\
X 1\end{array}$ & $\begin{array}{l}88.125 \\
88.038\end{array}$ & 88.082 \\
\hline 1014 & $\begin{array}{l}X 0 \\
X 1\end{array}$ & $\begin{array}{l}88.014 \\
88.026\end{array}$ & 88.020 \\
\hline 1016 & $\begin{array}{l}X 0 \\
X 1\end{array}$ & $\begin{array}{l}88.006 \\
87.999\end{array}$ & 88.002 \\
\hline 1017 & $\begin{array}{l}\mathrm{X0} \\
\mathrm{X} 1\end{array}$ & $\begin{array}{l}88.043 \\
87.990\end{array}$ & 88.016 \\
\hline
\end{tabular}

Grand Mean

88.056

$\pm 0.015$

$\pm 0.048$

$\pm 0.031$

$\begin{array}{ll}\text { of Mean } & \pm 0.015 \\ \text { between Vials } & \pm 0.048 \\ \text { between Aliquots } & \pm 0.031\end{array}$

(Difference $=+0.004)$

NBL

\begin{tabular}{|c|c|c|c|}
\hline \multirow[b]{2}{*}{ Sample ID } & \multirow[b]{2}{*}{ Aliquot ID } & \multicolumn{2}{|c|}{ wt $\% \mathrm{Pu}$} \\
\hline & & $\begin{array}{c}\text { Aliquot } \\
\text { Value }\end{array}$ & Vial Av \\
\hline 1004 & $\begin{array}{l}X 0 \\
X 1\end{array}$ & $\begin{array}{l}88.081 \\
88.029\end{array}$ & 88.055 \\
\hline 1007 & $\begin{array}{l}\mathrm{X} 0 \\
\mathrm{X} 0\end{array}$ & $\begin{array}{l}88.082 \\
88.079\end{array}$ & 88.080 \\
\hline 1008 & $\begin{array}{l}X_{0} \\
X_{1}\end{array}$ & $\begin{array}{l}88.085 \\
88.058\end{array}$ & 88.072 \\
\hline 1011 & $\begin{array}{l}X 0 \\
X 1\end{array}$ & $\begin{array}{l}88.020 \\
88.047\end{array}$ & 88.034 \\
\hline & & & \\
\hline
\end{tabular}

88.060

$\pm 0.009$

$\pm 0.021$

$\pm 0.023$ 
Table 5 - CHEMICAL ASSAY DATA FOR PLUTONIUM BATCH 2

(Common Decay Date 9/01\%76)

\begin{tabular}{|c|c|c|c|c|c|c|c|}
\hline \multirow[b]{3}{*}{ Sample ID } & \multicolumn{3}{|l|}{ Mound } & \multicolumn{4}{|c|}{ NBL } \\
\hline & \multirow[b]{2}{*}{ Aliquot ID } & \multicolumn{2}{|c|}{ wt $\% \mathrm{Pu}$} & \multirow{2}{*}{$\begin{array}{r}\therefore \\
\text { Sample ID } \\
\end{array}$} & \multirow{2}{*}{ Aliquot ID } & \multicolumn{2}{|c|}{ wt $\% \mathrm{Pu}$} \\
\hline & & $\begin{array}{c}\text { Aliquot } \\
\text { Value } \\
\end{array}$ & Vial Av & & & $\begin{array}{c}\text { Aliquot } \\
\text { Value }\end{array}$ & Vial Av \\
\hline 2015 & $\begin{array}{l}\mathrm{X} 0 \\
\mathrm{X} 1\end{array}$ & $\begin{array}{l}87.966 \\
87.902\end{array}$ & 87.934 & 2009 & $\begin{array}{l}\mathrm{X} 0 \\
\mathrm{X} 1\end{array}$ & $\begin{array}{l}87.896 \\
87.900\end{array}$ & 87.898 \\
\hline 2020 & $\therefore \begin{array}{l}\mathrm{X} 0 \\
\mathrm{X} 1\end{array}$ & $\begin{array}{l}87.946 \\
87.954\end{array}$ & 87.950 & 2001 & $\begin{array}{l}X 0 \\
X 1\end{array}$ & $\begin{array}{l}88.015 \\
87.975\end{array}$ & 87.995 \\
\hline 2017 & $\begin{array}{l}\mathrm{X} 0 \\
\mathrm{X} 1\end{array}$ & $\begin{array}{l}88.019 \\
88.058\end{array}$ & 88.038 & 2013 & $\begin{array}{l}\mathrm{X} 0 \\
\mathrm{X} 1\end{array}$ & $\begin{array}{l}88.010 \\
87.902\end{array}$ & 87.956 \\
\hline 2010 & $\begin{array}{l}\mathrm{X} 0 \\
\mathrm{X} 1\end{array}$ & $\begin{array}{l}87.969 \\
87.993\end{array}$ & 87.981 & 2005 & $\begin{array}{l}X 0 \\
X 1\end{array}$ & $\begin{array}{l}87.967 \\
87.907\end{array}$ & 87.937 \\
\hline 2019 & $\begin{array}{l}X 0 \\
X 1\end{array}$ & $\begin{array}{l}87.947 \\
87.907\end{array}$ & 87.927 & 2018 & $\begin{array}{l}\mathrm{X} 0 \\
\mathrm{X} 1\end{array}$ & $\begin{array}{l}88.006 \\
87.926\end{array}$ & 87.966 \\
\hline 2007 & $\begin{array}{l}\mathrm{X} 0 \\
\mathrm{X} 1\end{array}$ & $\begin{array}{l}87.968 \\
87.952\end{array}$ & 87.960 & 2012 & $\begin{array}{r}\mathrm{X} 0 \\
\times 1\end{array}$ & $\begin{array}{l}88.035 \\
87.979\end{array}$ & 88.007 \\
\hline & Grand Mean & & 87.965 & (Differer & $e=-0.005)$ & & 87.960 \\
\hline & Standard Dev & ation & & & & & \\
\hline & $\begin{array}{l}\text { of Mean } \\
\text { between Vials } \\
\text { between Aliqu }\end{array}$ & & $\begin{array}{l} \pm 0.012 \\
\pm 0.041 \\
\pm 0.026\end{array}$ & & & $\therefore$ & $\begin{array}{l} \pm 0.015 \\
\pm 0.040 \\
\pm 0.047\end{array}$ \\
\hline
\end{tabular}


Table 6 - CHEMICAL ASSAY DATA FOR PLUTONIUM BATCH 3

(Common Decay Date 9/01/77)

\begin{tabular}{|c|c|c|c|c|c|c|c|}
\hline \multirow[b]{2}{*}{ Sample ID } & \multirow[b]{2}{*}{ Aliquot ID } & \multicolumn{2}{|c|}{ wt $\% \mathrm{Pu}$} & \multirow[b]{2}{*}{ Sample ID } & \multirow[b]{2}{*}{ Aliquot ID } & \multicolumn{2}{|c|}{ wt $\% \mathrm{Pu}$} \\
\hline & & $\begin{array}{c}\text { Aliquot } \\
\text { Value }\end{array}$ & Vial Av & & & $\begin{array}{l}\text { Aliquot } \\
\text { Value }\end{array}$ & Vial Av \\
\hline 3109 & $\begin{array}{l}\mathrm{X} 0 \\
\mathrm{X} 1\end{array}$ & $\begin{array}{l}87.982 \\
88.046\end{array}$ & 88.014 & 3107 & $\begin{array}{l}\mathrm{X} 0 \\
\mathrm{X} 1\end{array}$ & $\begin{array}{l}87.957 \\
88.070\end{array}$ & 88.014 \\
\hline 3105 & $\begin{array}{l}\mathrm{X} 0 \\
\mathrm{X} 1\end{array}$ & $\begin{array}{l}87.991 \\
87.904\end{array}$ & 87.948 & 3101 & $\begin{array}{l}X 0 \\
X 1\end{array}$ & $\begin{array}{l}87.979 \\
88.034\end{array}$ & 88.006 \\
\hline 3108 & $\begin{array}{l}X 0 \\
X 1\end{array}$ & $\begin{array}{l}88.039 \\
88.015\end{array}$ & 88.027 & 3111 & $\begin{array}{l}\text { X0 } \\
\text { X1. }\end{array}$ & $\begin{array}{l}88.037 \\
88.029\end{array}$ & 88.033 \\
\hline 3106 & $\begin{array}{l}\mathrm{X0} \\
\mathrm{X} 1\end{array}$ & $\begin{array}{l}87.947 \\
87.931\end{array}$ & 87.939 & 3102 & $\begin{array}{l}\mathrm{X} 0 \\
\mathrm{X} 1\end{array}$ & $\begin{array}{l}87.860 \\
87.924\end{array}$ & $\therefore 87.892$ \\
\hline 3103 & $\begin{array}{l}X 0 \\
\mathrm{X} 1\end{array}$ & $\begin{array}{l}87.885 \\
87.908\end{array}$ & 87.896 & 3115 & $\begin{array}{l}\mathrm{X} 0 \\
\mathrm{X} 1\end{array}$ & $\begin{array}{l}87.968 \\
88.008\end{array}$ & 87.988 \\
\hline 3117 & $\begin{array}{l}\mathrm{X} 0 \\
\mathrm{X} 1\end{array}$ & $\begin{array}{l}87.996 \\
88.067\end{array}$ & 88.032 & 3113 & $\begin{array}{l}\mathrm{X} 0 \\
\mathrm{X} 1\end{array}$ & $\begin{array}{l}87.949 \\
87.917\end{array}$ & 87.933 \\
\hline & Grand Mean & & 87.976 & (Differe & $c e=+0.002$ & & 87.978 \\
\hline & $\begin{array}{l}\text { Standard Dev } \\
\text { of Mean } \\
\text { between Vials } \\
\text { between Aliq }\end{array}$ & ation & $\begin{array}{l} \pm 0.018 \\
\pm 0.056 \\
\pm 0.039\end{array}$ & & & & $\begin{array}{l} \pm 0.018 \\
\pm 0.054 \\
\pm 0.043\end{array}$ \\
\hline
\end{tabular}

Mound

NBL

?




$$
\begin{aligned}
& \text { Do Not } \\
& \text { Microfilm Distr. }
\end{aligned}
$$

\section{Distribution}

\section{EXTERNAL}

TIC, UC-15 (310)

H. N Hill, DOE, Dayton Area Office

R. K. Flitcraft, Monsanto Research Corporation

W. E. Koerner, Monsanto, St. Louis

R. E. Keller, Monsanto, St. Louis

R. M. Fritz, Monsanto, Texas City

P. Shapras, Monsanto, Springfield

R. Maute, Monsanto Research Corporation, Dayton

S. Dubelman, Monsanto, St. Louis

J. Goleb, DOE, OSS

G. Hammond, DOE,OSS

S. McDowell, DOE, OSS

W. Altman, NRC, Washington, D. C.

C. E. Pietri, NBL (10)

C. D. Bingham, NBL

Monsanto Reports Library, R2C, St. Louis

\section{INTERNAL}

L. R. Baird

W. T. Cave

P. A. Fitzharris

R. L. Goss

C. W. Huntington

C. Kinard

R. J. Seiler (5)

W. W. Rodenburg

D. R. Rogers

W. W: Strohm

R. E: Vallee

H. A. Woltermann

Publications

Library (15)

Published by Information Services

Patricia A. Fitzharris, Editor 